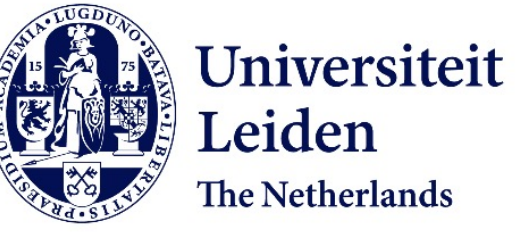

\title{
Global media and violence in Africa: The case of Somalia
}

Gewald, J.B.

\section{Citation}

Gewald, J. B. (2004). Global media and violence in Africa: The case of Somalia. In African dynamics (pp. 90-106).

Leiden: Brill. Retrieved from https://hdl.handle.net/1887/4852

Version: $\quad$ Not Applicable (or Unknown)

License: $\quad$ Leiden University Non-exclusive license

Downloaded from: https://hdl.handle.net/1887/4852

Note: To cite this publication please use the final published version (if applicable). 


\section{Global media and violence in Africa: The case of Somalia}

Jan-Bart Gewald

It has been argued that Africa has been sidelined in the global ICT revolution and that African societies appear to be cut off from global flows of information. Nevertheless, the manner in which war was waged in Somalia between 1991 and 1994 indicates that this global revolution has affected the manner in which war has come to be waged in Africa. African societies may indeed be cut off from owning and controlling the streams of images that reflect their continent, but they may, however, at times come to temporarily hijack and divert this stream of images, and ensure that images that stupport or reinforce their political aims come to be released into the global flow. In the case of Somalia, the real-time images of dead US soldiers being dragged through the streets of Mogadishu were sufficient to make the United States end their involvement in Somalia.

Introduction

Any form of good scholarship dealing with Africa would of necessity place African societies within the context of the wider and thus global world. The bulk of material dealing with Africa in the context of globalization has been dominated by economic studies, many of which fail to take cognisance of, let alone deal with, the social or cultural aspects of globalization. Fortunately, there is also a substantial amount of literature within the social sciences that deals with Africa in the context of globalization. Unfortunately some of this literature is esoteric, and thus generally unintelligible to the majority of readers, or anecdotal in the extreme.' It is often forgotten that anecdotes, though they may lead to complementary head-nodding and exclamations from admiring academic audiences, do not in themselves explain why events are taking place. Thus descriptions of Somali or Liberian gunmen bearing their arms in ways copied from US television shows may be interesting but do not explain why these men are taking up arms in the first place. ${ }^{2}$ Wars in Africa cannot be adequately explained merely through reference to fashion. This is not to deny that styles and images may influence the manner in which wars are fought. In his work on northern Tanzania, Brad Weiss explicitly states that his focus is on the interplay of 'the imaginary' and 'the global', and it is in dealing with imagination that he makes the following tantalizing remarks:

Far from (simply) an indulgence in escapist and illusory delusions, imaginative practice becomes essential to the very definition of reality as it is perceived and encountered. Conceived of in this way, fantasy becomes a medium through which to pursue the concrete processes by which consclousness is engaged in the world. A further insistence of many who address 'the imagination' is the recognition that such practices include far more than liberatory exercises in boundless, cultural creativity. Our interests in the imagination must incorporate the fantasies of ethnic cleansing and other brutalities as well as educational aspirations, regimes of mass consumption as well as utopian visions of democratic reform (Weiss 2001: 5 , emphasis added).

In other words, imagination does not only include the pleasing and desired aspects of life, but can also just as often come to include the darker side of life, fantasies that include the hurt and destruction of others. However, ideas and fantasies in and of themselves are not sufficient explanation as to why violence should occur. This is well presented by Clapham (2001) who, in dealing with developments in Sierra Leone, readily refers to aspects of a globalized popular culture in seeking to explain aspects of violence:

To be sure there could be those who would wish to argue that there is no need for academic literature to be intelligible to the majority of readers. However I do believe that the role of the academic is to seek to explain the world, and to do so in ways that are easily accessible to as large a group of people as possible

For an extreme example of this sort of material, see Amina Mama (2001), 'Gender in Action: Militarism and War' at: http://www.uct.ac.za/org/agi/papers/military.htm. For an overview of some of these perceptions to be found in the popular media, see Ottosen (1994) and Kennedy (1993)

${ }^{3}$ Regarding the human mind, evil imagination and destructiveness, interested readers may wish to see Erich Fromm (1973) The Anatomy of Human Destructiveness, New York: Holt, Rinehart and Winston. 
The products of an alienated American youth culture, notably the Rambo film 'First Blood' and gangster rap music, were readily reinterpreted in local terms as symbolising and legitimising resistance against a repressive official structure. (Clapham 2001)

Equally disturbing to the work that seeks to explain violence in terms of fashion, is that of the widely read and respected American commentator, Robert Kaplan (2001), who writes:

As anybody who has had experience with Chetniks in Serbia, 'technicals' in Somalia, Tontons Macoutes in Haiti, or soldiers in Sierra Leone can tell you, in places where Western Enlightenment has not penetrated and where there has always been mass poverty, people find liberation in violence. ... worrying about mines and ambushes frees you from worrying about mundane details of daily existence.

For Kaplan, isolated Africa has not attained a 'certain economic, educational, and cultural standard' that would 'tranquillize' physical aggression that he see as a part of being human. In other words, African primitives need to be civilized and, until this occurs, wars and violence will be the natural way of things in Africa.

There is a burgeoning literature that shows that the wars being fought out across the length and breadth of Africa are intimately connected to international global flows of weapons, drugs, diamonds and other trades. The work of Christopher Clapham, Stephen Ellis and Paul Richards on the wars in Sierra Leone and Liberia provide insight into the manner in which these wars take place within a global setting in which Africa is not an isolate. The genocide committed in Rwanda, and the subsequent Congolese wars, took place within a global context in which ethnic cleansing and crimes against humanity could be imagined - a context in which horrific examples of success are accessible and available to allow the imagined successful implementation of similar crimes against humanity. Yet to describe the violence committed in Rwanda, as the high priest of globalization studies Arjun Appadurai (1998: 905) does, as a vivisection of the body politic is assuredly poetic but far from explanatory.

bodily violence may be viewed as a form of vivisection, and as an effort to resolve unacceptable levels of uncertanty through bodily deconstruction. This approach may cast light on the surplus of rage displayed in many recent episodes of inter-group violence. ... such extreme and intimate violence may partly lie in the

${ }^{4}$ http://www.ippu.purdue.edu/failed_states/2001/papers/CLAPHAM2.pdf 'Kaplan's view of Sierra Leone is countered by Richards (1996) deformation of national and local spaces of everyday life by the physical and moral pressures of globalization.

It is generally accepted that the process of globalization has been in progress for decades, if not centuries. What is truly new in the last twenty years though has been the introduction of the electronic ability to compress space and time in a manner that is accessible to the majority of people on earth. The major difference with the past is the amount of information and the speed with which both information and real-time images can be transferred from one point on the globe to another. In the whole globalization discussion, it is this issue of spacetime compression that is the most important for our work. Having said this, it is necessary that examples as to how space-time compression has affected violence in Africa be presented. How has space-time compression qualitatively changed violence in Africa? An example of violent conflict in Africa is examined here and the role of space-time compression discussed therein. It is in effect an argument about a specific form of space-time compression, namely the local and highly contested use and appropriation of features of the global spread of mass media and mass communication."

\section{Globalization and Iraq}

In 1991 Peter Arnett, CNN's reporter-at-large, became the face and voice of the world's first globalized war. Standing on the roof of the Intercontinental Hotel in downtown Baghdad, Arnett covered the first air raids of the American-led Allied forces against Iraq. Television viewers around the world saw Operation Desert Storm unfold. At 3 a.m. in Baghdad, 1 a.m. in Amsterdam, and the

${ }^{6}$ See also Appadurai (1998: 906) 'Yet, to my knowledge, no single work has sought to explore the precise ways in which the ethnic body can be a theatre for the engagement of uncertainty under the special circumstances of globalisation'

Certainly telegraph and later telephone and even hrer wirese have been available from the 1860 s onwards, but only for a limited audience and only within specific settings. The major transformation is the availability of real time mass-media images and mass communication.

It has been in seeking to deal with the impact of globalization on Africa that the entire WOTRO globalization project was established in 1994.

${ }^{9}$ In his discussion of the information age, specifically in relation to questions of ownership, Castells (1997: 309-352) argues that the media, or rather access to media (the most effective political message to be found is the image that conveys a negative message. Politics has, according to Castells, become the domain of images of spin. 
beginning of prime time, 5 p.m. Eastern Standard Time in New York, antiaircraft fire streamed through the air, the streaks of tracer bullets clearly visible on television screens around the world. Surface-to-air missiles rocketed into the sky, their thunderous blue-to-orange exhaust trails sporadically dominating television images. Approximately half an hour after the anti-aircraft barrage had begun, the first incoming cruise missiles and other ordinance launched miles away began exploding in and around Baghdad. Explosions lit up the Baghdad skyline, and seconds later the rumbling sound of the same explosions reached Peter Arnett and his CNN news crew standing on the hotel rooftop in the centre of Baghdad."

Drinking bourbon and nibbling anchovies, $\mathrm{I}$, along with the rest of the modern world, watched on TV the opening stages of the world's first truly globalized media war. For 17 hours, thanks to the services of CNN and Peter Arnett, the world could see, live before their very own eyes, the unfolding of an allegedly new era of warfare, in which media, smart bombs and the near total absence of Allied casualties on the Alliance's side were the order of the day. This did not mean that there was no carnage." As the war progressed, Alliance forces killed tens of thousands of Iraqi conscripts. Iraqi soldiers came to be buried in their trenches by American bulldozers, Iraqi troops and Iraqi and Palestinian refugees fleeing Kuwait were strafed and killed, ${ }^{12}$ and the world's largest conventional ordinance, euphemistically known as the 'daisy cutter', ${ }^{13}$ was dropped on Iraqi positions. For all its extensive media coverage, this, the seedier reality of war, was not transmitted to the world's television audiences. Instead, they were presented with what became known as the 'Incubator Scam'.

${ }^{10}$ Peter Arnett no longer works for $\mathrm{CNN}$ but those interested can contact him directly via his personal website: http://www.peterarnett.com

"For an excellent first-hand view of the Gulf War by an American marine, see "For an excellent

'We fire and fire the AKs, a factory of firepower, the fierce scream of metal downrange and discharged cartridges and sand flying everywhere, now all of us shooting in the air, shooting straight up and dancing in circles, dancing on one foot, with the mad, desperate hope that the rounds will never descend, screaming, screaming at ourselves and each other and the dead laqis surounding us, screaming at ourselves and the dead world (he dead world. ... And I know we'll soon carry that mad scream home with us, but that no one will listen because they'll want to hear the crowd-roar of victory.

12 For a report on the 'Highway of Death', see URL: http://deoxy.org/warcrime.htm. This site contains a report compiled by Ramsey Clark who served as Attorney-Genera in the Johnson administration. Clark was convenor of the Commission of Inquiry for the International War Crimes Tribunal that presented the report in New York on 11 May 1991.

${ }^{13}$ For technical details and gung-ho views on the 'daisy cutter', see

http://www.fas.org/man/dod101/sys/dumb/blu- 82 .htm.
In it, the audience of the US television programme Sixty Minutes was presented with a bereft and distraught Kuwaiti nurse who stated that she had personally witnessed Iraqi troops throw new-born babies out of incubators in a hospital in Kuwait City. It was only later that this turned out to be a propaganda hoax, and the nurse none other than the daughter of the Kuwaiti ambassador to the United States. ${ }^{14}$

It is a truism, but the first casualty in war is indeed the truth. However, it has also been said that reality is what you can get away with. From the very beginning, the Gulf War was the mother of all media wars. Every evening for the duration of Operation Desert Storm, Allied commanders presented the world with clinically clean videogame images of missiles thudding into buildings and bunkers - and never any bodies. Norman Schwarzkopf, Colin Powell and others gloated at the Iraqi driver who failed to look in his rear-view mirror. Live, real time, in our living rooms, bars and workplaces, we watched beleaguered Israeli citizens collecting government-issued gas masks and sealing their apartments against imminent Iraqi attacks. American Patriot missiles rocketed into the night sky above Tel Aviv and allegedly intercepted incoming scuds, whilst crack British SAS teams sought out and destroyed mobile scud launch sites in Iraq. But, was it the truth? When Peter Arnett, now a well-known name, reported on the bombing and destruction of a baby-milk factory in a US bombing raid, CNN was put under pressure to ditch him. ${ }^{15}$ When journalists began reporting on the Highway of Death, the war was over, and nobody wished to entertain the suggestion that Alliance soldiers could ever have committed war crimes. ${ }^{\text {!b }}$

The Gulf War, which ended with American forces being feted in a tickertape parade through New York City, was - from the beginning to the end - a global media event. ${ }^{17}$ Live, the citizens of the world could see how the United States overcame its Vietnam syndrome and pounded home the truth that henceforth the United States of America was the Lone Ranger, the sole superpower answerable to none.

In the aftermath of the Gulf War, American military strategists, when analysing their total and devastating victory, took on board the concept of the 'Revolution in Military Affairs' (RMA), otherwise known as the 'Military Technical Revolution' (MTR). RMA is a concept that, interestingly enough,

${ }^{14}$ For a report on this fabrication and others like it, see http://www.fair.org.

In 1995, when Arnett returned to Baghdad, the baby-milk factory was back in production.

${ }^{16}$ This even though RAF pilots refused to take part in the carnage that was taking place.

${ }^{17}$ With regard to the first Gulf War, see, in particular, Baudrillard (1995). For a further interesting and humorous view on these issues, see Castells in discussion with Harry Kreisler: http://globetrotter.berkeley.edu/people/Castells/castells-con4.html 
developed out of what had initially been dubbed 'military technical revolutions' by Soviet military planners. In the 1970 s, Soviet military theorists identified py periods of fundary theorists recognized and began considering 'the implications for future war of technological advances in ( microelectronics, sensors, precision-guidance, automatedence, the American commission of inquiry on long-term defence strategy, submitted a report suggesting amongst other things:

Dramatic developments in military technology appear feasible over the next twenty years. They will be driven primarily by the further exploitation of microelectronics, Dears. They will be driven primarily by the further explont of directed particular sensors and information processing, and energy. These developments could require major revisions in military doctines and force structures... [T] he Soviet military estiobish new technologies, and appears to effort to understand the military implications of new technologies, and appears to have concluded that revolutionary changes in the nature of war will result. The much a greater precision, range, and destructiveness of weapons could extend war across a much wider geographic area, make war much more rapid and intense, and require entirelet al. 1988)

particularly with its emphasis on ICT, RMA is very much part Seen in this light, particularly waj singh and parcel of the process referre been brought about in what (1995-96), which emphasizes the changes that have been brought about in what he refers to as the 'Space-Time Paradigm' is particularly relevant here. In March 1993 the Center for Strategic and International Studies (CSIS) published a report entitled 'The Military Technical Revolution: A Structural Framework', in which it was declared that MTR was 'a fundamental advance in technology, n which it was declared that $M T R$ was a fundamentals of conducting warfare doctrine, or organization that renders existing mith the

obsolete' (cited in Watts 1995: 4). It was with
United States prepared to wage war in Somalia.

of The seeking a finely written and strident introduction are directed fofense Planning. The publication can be accessed at:

publicatisissipubs/pubs94/rma/rma.pdf

\section{Somalia}

'We know you better than you know us.' (Hassan al Tourabi)

Of late, al hadji Osama Bin Laden has appropriated a substantial amount of Of lis ever-extending fifteen airtime on the world's various media networks. In his ever-extents in Somalia proved to him that the United States of America could be beaten

The end of the Cold War had serious implications for states in Africa." In the Horn of Africa, Somalia and Ethiopia were countries that had vacillated between Soviet and US support. In both instances the withdrawal of superpower support for their respective regimes had major implications. Ethiopia came to be divided into two separate states, and Somalia collapsed into anarchy. In March 1991, US Assistant Secretary of State Herman Cohen declared Somalia to be a civil strife disaster, after which the Office of Foreign Disaster Assistance began funding relief efforts there.

Immediately after the Gulf War, the position of George Bush Sr. as president of the United States of America appeared unassailable. However, the substantial public support that Bush had enjoyed evaporated by the middle of 1992. In the immediate run-up to the presidential campaign, the Bush administration immediate run-up to the prident's ever worsening position. On 14 Augus attempted to shore up the president's 1992, a month prior to the start of the presidential campaign, the Bush administration turned its attention to Somalia again and ordered a major airlif of relief supplies (Operation Provide Relief).

Operation Provide Relief, like other attempts to provide relief to the starving

Somalia, ground to a halt and in the absence of a centralized authority, relief in Sonalia, ground to a halt and in the absence of a centralized authority, relief workers were unable to transport goods to their intended destinations. In keeping with the logic of a scarce market, a situation had developed in Somalia in which a multitude of armed factions demanded taxes prior to allowing the transportation of food aid through their territory. Without protection, food convoys were unable to move and calls for solid and sustained military intervention in support of the food convoys were voiced. In November, with the intervention in support of the food convoys were voiced. In November, wh the presidential elections over, US aid agencies and members of Congress lobbied to have the US take greater action in Somalia. Undoubtedly, George Bush Sr, who had just been crushingly defeated in the presidential elections by Bill Clinton and had seen his stature fall from all-conquering world leader to

19 Dr Hassan al Tourabi is a graduate of the University of Oxford and the Sorbonne, founder of the Sudanese National Islamic Front, and a former friend and colleague of Osama Bin Laden.

${ }^{20}$ Regarding the ending of the Cold War and its impact on Africa, see, amongst others, Akinrinade (1998), Oyebade \& Alao (1998) and Furley (1995). 
$98 \quad$ Gewald

unpopular president, saw in the situation that was developing in Somalia an opportunity which could allow his presidency to end with a positive flourish, the proverbial history books as a good and benevolent president. ${ }^{23}$

To the world's sole superpower, the assorted and factious gunmen scattered

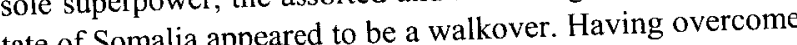
across the former state of Somalia appeared to be a wited States of America their Vietnam syndrome in the Gulf War, the United

proceeded to walk slap bang into the Somalia syndrome.

At the end of November 1992, the outgoing Bush administration decided to commit 28,000 US troops to spearhead an armed intervention in Somalia in support of UN relief efforts. On 4 December, the United Nations Secuity Council voted to support US intervention, and George Bush went live on television to address the nation:

Law and order have broken down. Anarchy ent in Somalia. Law and order have broken down. Ane safe prevails. ... It's now clear that military support is necessary to ensure the safe delivery of the food Somalis need to survive. ... And so, to every sailor, soldo God's airman, and Marine who is involved in the United States of work. We will not fail. Thank you, and may God b America. ${ }^{22}$

From the very beginning, Operation Restore Hope was a major media event Work conducted elsewhere indicates that it was only following Bush's decision Work conded. In other words, to intervene that media coverage of Somalia truly expand contrary to voiced opinion, media attention had in itself not been responsible for the president's decision to intervene (Robinson 2000, 2002). Though printed media coverage increased substantially, it was specifically in the sphere of live television coverage that truly absurd situations developed. In the days abent, media teams from the competing

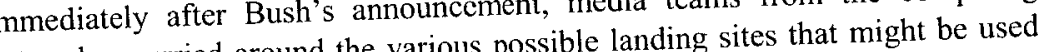
networks scurried around the various possible landing sitable generators, set up by the intervention force. Camera crews, some with portable generans, se us camp at what appeared to be the most likely landing sites. In the event, the US Joint Chiefs of Staff did not disappoint the many and varied media concerns. In Joint Chiefs of Staff did not disappoint the the early hours of 9 December 1992, heavily armed US marines and Navy Seals

ther far more sinister line of reasoning that relates US is intervention in Somalia to the machinations of Bush and is in Somalia', an article by prospecting rights on Somali territory. See The Oil Fact

Mark Fineman in the Los Angeleman.html

列

A similar view can be found at: http://www.casi.org.uk/discuss/2001/msg01/43.html

${ }^{22}$ President Bush's address to the nation on 4 December 1992, cited in Robinson (2001). landed on the beaches around Mogadishu in a blaze of flashbulbs and live worldwide television coverage.

Live, real time, those preparing evening meals for their loved ones in New York City could watch as, halfway round the world, US forces - who were the enitome of Hollywood's finest soldiers - stormed ashore. In the nights prior to the US forces' landing, camera crews had anxiously peered out to sea, providing their worldwide audiences with expansive shots of an empty sea accompanied by newspeak debating and announcing the imminent arrival of American forces. Whe newsent spokesmen chided When the forces did finally arrive, irate Defence Depa the media crews for being there, not realizing the apparently precarious and dangerous nature of their position. If anything, the landing of America's finest to emphasize to all on the shores of Somalia in a blaze of publicity served to emphasize to all

observers the importance of publicity and media in the modern world. And
Purvis, a journalist currently working for Time magazine, recently wrote:

was on the beach when US troops arrived in Mogadishu in 1992, and the feeling I was me that tempestuous night was a mixture of euphoria and awe. Most Somalis around the US deployment, waving as Navy Seals in face paint and genuinely welle help rid them of the black camouflage waded ashore. They believed the US anarchy and famine that had already left tens of thousands dead. AK-47-toting militiamen in their cloth wraps and rubber sandals were also impressed by the military show, not knowing what the US colossus was capable of. Within a few months, all that had changed. (Purvis 2002)

Prior to becoming involved in Somalia, the US National Security Council commissioned think tanks in the United States to submit reports recommending what was to be done should the United States choose to intervene in Somalia. what was to be done should the United Intervention in Somalia', was drawn up An operational cornegie Endowment for International by Frederick $\mathrm{C}$. Cuny Peace and the Cent from listing recommendations with regard to the operational concept Objectives, Force Structure, Security Zones, Exclusion Zones, and so forth the eleven-point plan included the following final paragraph:

The most troublesome element is the likelihood of sniping. There will undoubtedly be be

flat and open. The most likely place for sniping will be Mogadishu since it alone

${ }^{23}$ A copy of this report is to be found at:

http://www pbs.org/wgbh/pages/frontline/shows/cuny/laptop/somalia.htm. 
100 Gewald

offers concealment and escape possibilities. For this reason, it is strongly recommended that US and allied forces stay out of the city. ${ }^{24}$

Three days after landing in Somalia, American forces were in combat. From then onwards, with intermittent periods of relative calm, they became drawn ever deeper into war. After being initially overawed by the intervention force Somali combatants came to challenge American forces increasingly openly. Within a month of their arrival, American forces had identified Mohammed Farah Aidid as their primary opponent. On 12 January 1993, the first marine was killed whilst on patrol in Mogadishu and from then onwards, slowly but surely, Somali combatants gained in confidence, and the American forces were constantly harassed by snipers operating in the city. Time and again, even though gun ships attacked Somali positions, American forces were subjected to surprise attacks. Eventually, after seven months of bungling, many wounded and a number of dead, members of the $3^{\text {rd }}$ Battalion $75^{\text {th }}$ Ranger Regiment and the $1^{\text {st }}$ Special Forces Operational Detachment (DELTA) were deployed to Somalia with orders to capture Aidid. In conjunction with this deployment, Operation Eyes Over Mogadishu was started. It entailed round-the-clock surveillance of Mogadishu by Lockheed Orion surveillance planes and helicopters supported by helicopter gun ships, and helicopter troop carriers.

America's involvement in Somalia was predicated on a positive media image: American forces guarding food-aid convoys and aiding the starving and needy. This image changed completely when Wild West 'wanted' posters bearing Aidid's image appeared throughout Mogadishu..$^{25}$ In support of these posters, and in an attempt to minimize American casualties:

The U.S. launched its campaign from the air, using attack helicopters and AC-130 Specter gun ships to carry out what military analysts confidently described to the world's media as 'surgical' strikes. They were not. In the most notorious incident to Somalis, anyway - Cobra gun ships blasted a tall white stucco building in central Mogadishu in July 1993. The target was a well-publicized meeting of clan elders loyal to Aidid but the victims, some 70, included innocent civilians. Word of the strike spread quickly through Mogadishu's alleyways and coffee houses. When a

${ }^{24}$ The Operational Concept Plan justified its recommendation that American forces refrain from entering Mogadishu by referring directly to the costly lessons learnt by the Indian army in its failed operations in Jaffna Town in Sri Lanka, and suggested that, should Mogadishu be included the British should be encouraged to 'commit an experiened force ex Norten Iretand to nanage the irregular urban warfare threat'. ${ }_{25}$ Robert Oakley, US Ambassador to Somalia between November 1992 and May 1993 noted that the reward of US $\$ 25,000$ was an insult. http://www.pbs.org/wgbh/pages/frontline/shows/ambush/interviews/oakley.html handful of foreign journalists arrived at the scene, Somalis, including women and children, turned on them and beat four to death. (Purvis 2002)

The killing of the four western journalists unleashed a storm of protest in the West, and must have provided Aidid and his planners with an indication as to how they could strike back at the 'Lone Ranger'.

But who was Mohammed Farah Aidid, the man so anxiously sought and vilified by the Americans? Aidid had been a general in the Somali national army, and as such had enjoyed military training in both the East and the West. ${ }^{20}$ In the late 1980s Aidid was instrumental in deposing the Somali dictato Mohammed Siad Barre and in the ensuing chaos in which Somalia came to be torn apart, Aidid became president of what remained of Somalia. Even so, American forces treated him with the utmost contempt, placed a price on his head and declared him a bandit, a thug and a warlord. To be sure, this view of Aidid was reinforced every time militiamen allied to Aidid demanded payments and prevented food convoys from moving through areas under their jurisdiction. Nevertheless, the truth remains that he was simply dismissed as a serious opponent, yet he - more than any other general since Giap - defeated American forces at their own game.

Aidid was effectively trapped in Mogadishu, yet to all observers it was clear that the United States was reluctant to commit forces on the ground in the city. Instead, as was noted above, US forces preferred to attempt to reach their objectives by pounding their alleged opponents with cannon fire from the air Dropping specialized units from helicopters into the city complemented this strategy. In keeping with Operation Eyes Over Mogadishu, helicopters continually flew over the city, aircraft that - as Aidid's forces so capably showed - could be shot down with the simplest of weapons. On 3 October 1993 an American helicopter attempting to 'exfiltrate' an American unit was shot down by a RPG 7, a simple shoulder-fired rocket-propelled grenade. The aircraft crashed and was immediately surrounded and attacked by Aidid's soldiers. When another American helicopter attempted to provide support for the downed aircraft, it too was shot down, also by an RPG 7. With two of thei aircraft shot down in the city, American forces attempted to reach them overland but to do so they too had to enter the city - terrain held by Aidid's forces. American armoured personnel carriers sent into the city ran into ambushes. ${ }^{27}$ In this single event, an estimated 1,500 to 2,000 Somalis, including

${ }^{26}$ Mohammed Farrah Aidid's son and successor, Hussein Mohammed Aidid, possessed American citizenship and returned to Somalia as a US marine in 1992. See: http://news.bbc.co.uk/hi/english/world/africa/newsid 1146000/1146654 stm ${ }^{27}$ For a profoundly disturbing view of these events: http://www.angelfire.com/ne2/somalia/enter.index.htm 


\section{Gewald}

non-combatants, were killed and wounded, whilst 18 US servicemen were killed and no less than 78 wounded. ${ }^{28}$

American forces had effectively flown, driven and crashed into a terrain in which all of their high-tech communications equipment counted for nought Citations for 'Medals of Honor', posthumously awarded by the US army to two of its snipers killed in the events of 3 October, clearly indicate the nature of the terrain:

When debris and enemy ground fires at the site caused them to abort the first attempt, Sergeant First Class Shughart and his team leader were inserted on hundred meters south of the crash site. Equipped with only his sniper rifle and pistol, Sergeant First Class Shughart and his team leader, while under intense smal arms fire from the enemy, fought their way through a dense maze of shanties and shacks to reach the critically injured crew members. Sergeant First Class Shughart pulled the pilot and the other crew members from the aircraft... ${ }^{29}$

The pilot, Chief Warrant Officer Michael Durant, survived the engagement but was captured by Aidid's forces.

Immediately after the battle, on the morning of 4 October, jubilant Somalis dragged the body of an American soldier through the streets of Mogadishu. CNN broadcast these unedited images live to the world. Abdullahi Hassan, who acted as Aidid's propaganda minister, arranged for CNN to receive a copy of the video footage of the captured pilot stating: 'Innocent people being killed is not good'. Durant was held captive for eleven days by Aidid's forces during which time Abdullahi Hassan allowed the competing media networks access to Durant and the world received images of a frightened young American being held captive and being cared for by the followers of Aidid. He told Mark Huband, a journalist with The Guardian:

Too many innocent people are getting killed. People are angry because they see civilians getting killed. I don't think anyone who doesn't live here can understand what is going wrong here. Americans mean well. We did try to help. Things have gone wrong.

Within a month of Durant's capture, all American servicemen had been withdrawn from Mogadishu. Aidid had defeated the world's sole superpower

${ }_{28}$ Malaysian and Pakistani soldiers assisted the American forces that entered 28 Malaysian and Pakistani soldiers assisted the American forces that entered
Mogadishu. Many of them were also killed and wounded. Robert Oakley (US Ambassador to Somalia) estimated the number of Somali casualties in an interview with PBS: www.pbs.org/wgbh/pages/frontline/ shows/ambush/interviews. See also Hirsch \& Oakley (1995).

${ }^{29} \mathrm{http} / /$ www.army.mil/cmh-pg/mohsom.htm. and, as Osama Bin Laden has been happy to point out, Somalia proved that America could be defeated.

In Somalia, Mohammed Farah Aidid hijacked the weapons of the powerful and used them for his own aims. The US intervention in Somalia was determined and defined by the media and in the aftermath of the Gulf War, the US public had come to expect and anticipate clean real-time live images of their men doing 'God's' work. That this medium could also provide them with realtime live images of mangled American bodies and frightened captured young men had not been anticipated, and no amount of spin-doctoring could prevent it. In Somalia, Aidid took control of, if only for a short period of time, part of the arsenal of ICT superiority that the US had, and used it against them. Hungry for their media ratings, international media companies struggled with one another to scoop the images that would terminate America's involvement in Somalia and subsequently Rwanda. Direct real-time images of death and destruction, a development that had been made possible by the rapid advances in ICT, spread around the world. From Tokyo to Johannesburg, Sao Paolo, New York and San Francisco, audiences heard the words and saw the face of the frightened young pilot urging America to withdraw, and within the space of a month America withdrew.

There was no longer any support for the US to engage Somalis in combat as far as the US public was concerned. The impact of Americans being dragged through the streets, a large number of Americans killed and wounded without any real explanation by the White House, in advance, of why we were there. The fact that the mission was no longer a humanitarian mission. That we were somehow engaged in a war and why this war was worthwhile meant that there was no support whatsoever for any sort of active operation, other than self-defense military operations in Somalia. ${ }^{30}$

The reaction by the United States to events in Somalia had wide-ranging repercussions. Bosnian Serbs publicly celebrated developments in Somalia, secure in the knowledge that they would never have to face US troops in faceto-face combat (Power 2002). With events in Somalia in mind, Rwandan extremists planning to commit genocide developed a plan of action that would guarantee the withdrawal of foreign European troops from Rwanda. On 11 January 1994, Major General Romeo Dallaire, the Canadian officer commanding the United Nations Assistance Mission of Rwanda (UNAMIR) contacted UN headquarters in New York and transmitted a coded cable via satellite. The cable proves that by as early as January 1994, the world had knowledge about the impending genocide. In his cable Dallaire referred to a

${ }^{30} \mathrm{http} / /$ www.pbs.org/wgbh/pages/frontline/shows/ambush/interviews/oakley.html 
Rwandan informant, a 'very very important government politician. ... is a top level trainer in the cadre of interhamwe'

He informed us he was in charge of last Saturday's demonstrations whose aims were He infortian soldiers. to target depentrators They hoped to provoke the RPF BN to engage (bcing fir and provoke a civil war. Deputies were to be assassinated upon entry or exit from Parliament. Belgian troops were to be provoked and if Belgians soldiers resorted to force a number of them were to be killed and thus guarantee Belgian withdrawal from Rwanda."

Hijacking the powerful

Castells has noted that one of the prime constraints on the fighting of wars for rich countries is the flow of information:

It's not just that people no longer feel there are values worth dying for, but their ability to get information about what's happening on the battlefield is the kind of information flow that leaders who want to engage in war have to respond to, and are therefore forced to get out of the war quickly. ${ }^{32}$

That this is the case has been clearly brought to the fore by what happened in Somalia and later Rwanda. In both cases, the weapons of the powerful - here the media - could and can be hijacked for a short period of time and then released again. This temporary ownership has effects and results that are totally unintended on the part of the powerful. In and of itself there is nothing new about the images being presented, yet what is new is the speed, pervasiveness and quantity of the material being presented. When the Germans were defeated in battle in Namibia in the late $19^{\text {th }}$ century it took at least four months before the defeat could be avenged, yet when Aidid shot down a helicopter above Mogadishu, the change was immediate. The example of Somalia indicates that there is a struggle for access to media streams. It also highlights the need for further study on how local actors use international media streams to advance their own aims that is a move away from the anecdotal and a move into the concrete. In essence, the case of Somalia is a further example of the struggle, on the part of Africans, to develop ways and means with which to divert and hold,

${ }^{31}$ A copy of this cable is to be found at:

htt///w of

${ }_{32} \mathrm{http} / /$ globetrotter.berkeley.edu/people/Castells/castells-con $4 . \mathrm{html}$ even if for only a limited amount of time, the streams of information and goods that flow around the globe.

\section{References}

Akinrinade, S. 1998, Africa in the Post-Cold War International System, London: Pinter. Appadurai, A. 1998, 'Dead Certainty: Ethnic Violence in the Era of Globalisation', Development and Change 29 (1998): 905-25.

Baudrillard, J. 1995, The Gulf War Did Not Take Place, Bloomington/Indianapolis \& Sydney: Indiana University Press \& Power Publications.

Castells, M. 1997, The Power of Identity: The Information Age - Economy, Society and Culture, Oxford: Blackwell Publishers, pp. 309-52.

Clapham, C. 2001, 'Sierra Leone: The Global-local Polities of State Collapse and Attempted Reconstruction', Paper prepared for the Failed States Conference, Florence, 10-14 April

Furley, O. 1995, Conflict in Africa, London: Tauris Academic Publishers.

Hirsch, J.L. \& R.B. Oakley 1995, Somalia and Operation Restore Hope: Reflections on Peacemaking and Peacekeeping, Washington: United States Institute of Peace.

Iklé, F.C. \& A. Wohlstetter et al. 1988, 'Discriminate Deterrence', Washington DC: US Government Printing Office, p. 8, cited in: B.D. Watts, What Is RMA, What Is the 'Revolution in Military Affairs', Northrup Grumman Analysis Center 703 (351): 3.

Kapian, R.D. 1994, 'The Coming Anarchy: How Scarcity, Crime, Overpopulation and Disease are Rapidly Destroying the Social Fabric of our Planet', Atlantic Monthly February

Kennedy, F. 1993, 'In Somalia, Machiavelli vs. Rambo', New York Times, 22 July.

Mazarr, M., J. Shaffer \& B. Ederington 1993, 'The Military Technical Revolution: A Structural Framework', Washington: CSIS.

Ottosen, R. 1994, 'Rambo in Somalia? A Critical Look at the Media Coverage of Operation Restore Hope', Paper presented to the $6^{\text {th }}$ MacBride Round Table, Honolulu, Hawaii, 20-23 January.

Oyebade, A. \& A. Alao 1998, Africa After the Cold War: The Changing Perspectives on Security, Trenton, NJ: Africa World Press.

Power, S. 2002, 'Genocide and America', The New York Review of Books, 14 March.

Purvis, A. 2002, 'One Lesson Worth Remembering', Time, 20 February.

Richards, P. 1996, Fighting for the Rain Forest: War, Youth \& Resources in Sierra Leone, Oxford: James Currey.

Robinson, P.G. 2000, 'The News and Intervention: Critical Media Coverage, Policy Uncertainty and Air Power Intervention During Humanitarian Crisis', Paper for the Political Studies Association UK $4^{\text {th }}$ Annual Conference, London, 10-13 April.

Robinson, P.G. 2001, Operation Restore Hope and the Illusion of a News Media Driven Intervention, Oxford: James Currey.

Robinson, P.G. 2002, The CNN Effect: The Myth of News Media, Foreign Policy and Intervention, London: Routledge. 
Singh, A. 1995-96, 'Time: The New Dimension in War', Joint Forces Quarterly, Washington DC: National Defence University, Winter.

Swofford, A. 2003, A Marine's Chronicle of the Gulf War and Other Battles, New York: Scribner.

Watts, B.D. 1995, What Is the 'Revolution in Military Affairs', Northrup Grumman Analysis Center 703 (351): 2.

Weiss, B. 2001, 'Thug Realism: Inhabiting Fantasy in Urban Tanzania', Cultural Anthropology 17 (1): 1-32. 